\title{
Travel in Tropical Islands: Enemies coexisting in Peace
}

\author{
A.-Chr. Engels-Schwarzpaul
}

An 1851 Punch cartoon of the London World Exhibition shows a "European rider with a spiked helmet" racing closely "behind the African elephant and next to an American Indian" (Kaiser, n.d.). They waste no time on taking notice of each other, but scramble furiously towards the finishing line. Meanwhile, contemporary debates nurtured pious hopes that intercultural encounters at the exhibition would further mutual understanding and world peace. Likewise, Sigfried Giedion optimistically remarked of the Exhibition: "To take a turn about this place ... is literally to travel around the world, for all nations have come here; enemies are coexisting in peace"(in Benjamin, 2002: 175-6).

In 2006, a Tropical Village at the Tropical Islands Resort at Brand, $60 \mathrm{~km}$ southeast of Berlin, features several houses from tropical regions, a Samoan Fale in their midst. Set on an oval, elevated platform, the Fale signals the South Seas' eternal sun and balmy breezes. Its handcrafted Pandanus mats, carved posts, weaving and lashing details tell of an imaginary place where time moves at a different pace. As part of the $€ 70$ million themed resort, the Fale is sheltered under a 360 meter-long steel dome: indeed, an ex-CargoLifter hangar.
Many thanks to Ross Jenner, Nina Corsten, Albert Refiti, Mark Jackson, Julia Gatley, Frances Edmond and the two blind reviewers for valuable comments and criticism.

Both scenarios stage notions of progress, nostalgia and exoticism. In their creation of global public spaces, both combine labour and leisure in peculiar ways, so that Giedion observed enemies coexisting in peace, while the Tropical Village has been labelled a "One-World-Village" (Eine-Welt-Dorf). These tropes orient experience, shape perception and activate knowledge. But which knowledge? The Punch cartoonist and Giedion registered competitive conflict and peaceful coexistence in the same setting. And while Chinese-Malaysian multi-millionaire Colin Au planned the resort to satisfy a Germanic yearning for sun (unmatched by expendable incomes and geographical location: "I've done my research and I know how the Germans tick"; in Connolly, 2004), some disagreement accompanied Tropical Islands' establishment, as will be discussed later. What is visible of the Fale today says little about its origins; and Germans, it seems, have forgotten about their past involvement in Samoa.

Jacques Rancière and Walter Benjamin share an interest in the relationships between different modes of art and politics: ways in which perception and language set up pictures of the world; and in the productive potential of conflict to open up new spaces of visibility. Thus, they may offer pointers regarding the potential of Tropical Islands to aid or prevent the appearance of different forms of relationships. 
I. "... politics is ... an aesthetic conflict. Not at all in the sense of the aestheticization of politics analyzed by Benjamin, but in the sense that politics in general is about the configuration of the sensible, about questions such as what is given, what is terrible about it, who is visible as a speaker able to utter it" (Rancière, 2003a: §5). Rancière's assertion that Benjamin treats art and politics as separate entities seems overstated: "What we may register in Benjamin's juxtaposition is both an account of the partition of the sensible within a given artistic practice and an investigation of the effects of an artistic partition of the sensible upon a political one" (Toscano, 2006). See also Benjamin (1969c: S VII).

2. For a critique of Pièrre Bourdieu, see Rancière (2006: 3-4) and Hallward (2006: §37).

3. Rancière (2004: 6) opposes the police (as the administrative apparatus defining appropriate "ways of being, doing, and saying") and politics (as actions that call into question the existing divisions between common and private, or visible and invisible). See also Ostwald's contribution in this issue, page 8 .

4. Through this account runs Aristotle's distinction between "those who possess language and those, like slaves, who can only understand", having only "cries of hunger, rage, or hysteria" (Rancière, 2004: 5): there are those who are visible, because they can argue, and those who remain invisible, because they cannot. Their relationship is one of mésentente - of "'the fact of not hearing, of not understanding' and 'quarrel, disagreement"' (5). Perhaps Rancière settles too quickly for the translation of mésentente as 'disagreement'. The German translation, Unvernehmen or Unstimmigkeit, is more multivalent. 'Disagreement', as one element of politics as dissensus (as opposed to the consensus in contemporary regimes under the rule of police) may not account for certain processes where no engagements occur where "a dispute over the situation itself, ... over what is visible"

\section{Regimes of visibility: Aesthetics and politics}

Rancière sets apart his approach from Benjamin's notion of the "aestheticization of politics": he sees the assumption that politics are not originally aesthetic as false. ${ }^{1}$ This setting-apart rests on his definitions of aesthetics and politics. For Rancière, aesthetics is not a theory of the beautiful (opposed or complementary to knowledge), but an intrinsic dimension of knowledge (2006: 1). When art suspends "the ordinary coordinates of space and time that structure the forms of social domination", shapes "a specific sensorium", it is political (2005). Correspondingly, a (Kantian) disinterested aesthetic experience, with its temporary deferral of normal social conditions, can enable a different way of seeing (2006: 2): " "Spectacles which disassociate the gaze from the hand and transform the worker into an aesthete" (9) havethepotential to disrupt theconsensusofanestablishedorder. ${ }^{3} T h e n$, politics happens through disagreement, through an "aesthetic conflict" over the "configuration of the sensible", the "visibilities of ... places and abilities of the body in those places, ... about the very configuration of the visible and the relation of the visible to what can be said about it" (2003a: S5). ${ }^{4}$ In political dispute, the argument is often "first of all on the legitimacy or even the reality" (Holmes, 2001) of what configures disagreement.

Similarly, Benjamin wagers on disruption, against consensus, to change a status quo that is really a continuous state of emergency. Conflict between what is and is not, or can and cannot be, is, for him, the very energy driving the endless renewal of language (1969a: 320; 1969b: 79). Conflict, but also complementation and redemption, is part of the vital relationship between an original and its translation. As the original's afterlife, a translation releases, in a different language, what remained repressed in the original (1969b: 80). Changed and non-identical, it represents and expresses "the central reciprocal relationship between languages" (72). Thus, in diverse ways, languages configure the experience of perception. Aesthetics, as this experience, derives from "aisthesis: the appearance of that which, of itself, shows itself" (Mersch, n.d.: S3), and is "perceptive by feeling" (Buck-Morss, 1992: 6). Sensory perception (taste, touch, hearing, seeing, smell) "refers to symbols" (Benjamin, 1996: 92) which, like language, configure differently what can be said about the sensible. Thus, aesthetics constitutes an historically specific mode of visibility and intelligibility, not of art alone. Politics impacts on visibility by creating a theatrical space for new and disparate things to appear; it sets up a stage where the hitherto unconnected may be connected (Rancière, 1999: 88). Art and politics share an uncertain reality, and movements from the political to the aesthetic are inherent in the political itself. Metaphorical displacement may shift a community's perception of "the relation between a situation and the forms of visibility and capacities of thought attached to it" (2006: 9), so that new objects become visible and thus available to thinking. Once such changes have been reintegrated into a "generally accessible mode of reasoning or form of language", a collective creative reconfiguration of the common world of experience becomes possible (2000a: 116).

With respect to both art and politics, Tropical Islands Resort's status is uncertain. For instance, as with many other non-European art forms, that of the Samoan tufuga (master builders) was long denied the status of art within Western frameworks. On the other hand, claims to the status of art are increasingly made in the entertainment industries. ${ }^{5}$ It would be impractical and elitist to rule out the 
possibility that some phenomena at Tropical Islands may qualify as art: they may indeed shape a specific sensorium, suspend the ordinary coordinates of space and time, open up new ways of seeing, and reconfigure a common world. ${ }^{6}$ Do they, however, lend themselves to politics? Does Tropical Islands afford potential for creative reconfigurations through conflict or disagreement?

According to Rancière, it is the conflict about what can or cannot be expressed that allows a controversial world to be polemically framed within the given one. In contrast, consensus, far from simply being an agreement between political or social partners about shared interests, "properly means the dismissal of the 'aesthetics of politics'” (2003c). It suppresses the need of the outsider to create "another way of seeing than that which oppresses them" (2006: 3).

\section{From World Exhibition to Theme Park}

Consensus, like politics, is produced: for instance, during the heyday of imperialism it was important for imperial nations to create internal consensus by appealing to national pride in progress and technological achievements. Thus, French national and municipal bodies gave away to workers hundreds of thousands of free tickets for the World Exhibitions (Benjamin, 2002: 186), and French workers' delegations were sent to the 1851 London World Exhibition (188). Benjamin called the exhibitions "training schools in which the masses, barred from consuming, learned empathy with exchange value. 'Look at everything; touch nothing'" (201). Those who entered were distracted by the phantasmagoria of a "universe of commodities" (8) contained in an interiorized world. "Cut off from the will of man," the commodity performed "as an actor on a phantom stage" (182), and visitors themselves shared much with the commodity. Surrendering to the manipulations, they enjoyed their alienation from themselves and others (2002: 7). ${ }^{7}$ Perception as much as thinking was affected, as reality was adjusted to the masses and the masses to reality (1969d: 223).

The interior of the 1851 Crystal Palace was designed for an exhibition of the world in a village (see Kaiser, n.d.) - for a global public from diverse social backgrounds and numerous countries. However, what was staged in the village was, predominantly, English and French industrial displays - in contrast to performances of the simple life of 'natives' from the colonies. This strategy would be employed repeatedly at later world exhibitions and smaller shows. Exotic displays, compensating for a widely felt loss of authentic tradition in Europe, played out a series of spatial tropes (DiPaola, 2004: 328-31), which structured the experience of the strange, and changed European perceptions of self and other. A trope, of course, is a rhetorical device. From the Greek "a turn", it shifts our perception and the way we make sense of the world. Thus, in nineteenth century German literature on Samoa, a strange exterior space, exotic and abundant nature, morphs into interior space, a zoological or botanical garden, to be filled with homely elements and commonplace exotic images. In a strange cultural space, childlike, happy and naïve noble savages wait to be civilized. These tropes are overlaid and interlaced by a space of erotic power where fragments of the strange woman blend with fruit and flowers, and the strange colonial territory is appropriated metaphorically through the sexual act between colonizer and native woman. ${ }^{8}$ and over "which visible elements belong to what is common" cannot take place. While Rancière registers a growing demand for consensus in Western societies, obscuring the "contestatory, conflictual nature of the very givens of common life" and replacing political difference with "police-like homogeneity" (7), he does not address configurations where a lacking common world precludes sufficient political conflict, which could then reorganise the "division of perceptible givens" (6) to transform "one world into another" (7).

5. "At the end of the day, video games ... are pieces of art" (The Mark of Kri on Playstation 2 2003).

6. The "autonomy staged by the aesthetic regime of art is not that of the work of art, but of a mode of experience" and "the object of that experience is 'aesthetic', in so far as it is not-or at least not only-art" (Rancière, 2002). Depending on the reference framework, art could be either "political to the extent that it is merely art", or, "to the extent that it is art no longer" (2005).

7. Regarding workers' delegations, Rancière (2003b: 73) gives a somewhat different account, emphazising that, on the scene, a spectacle of machines was staged while, offstage, the workers were dispossessed of their work and their lives.

8. These tropes (described by DiPaola for German literature of the time) appear, for instance, at the 1896 Samoan Show at the Zoologischer Garten in Frankfurt (see Steffen-Schrade, 1998) and survive into current tourism marketing: "South Seas paradises replete with tropical fruit, naked women and free love" (Beuchelt, 1987: 98). In the $19^{\text {th }}$ century, zoological gardens were, along with dioramas and panoptica, preferred venues for the exhibition of exotic natives. Their performances, choreographed with elaborate dramaturgic effects, were inserted into exotic dreamscapes, and the zoos' architectures increasingly alluded to the animals' places of origin, for instance in Berlin during the 1870 s (Goldmann, 1987: 88-89). 


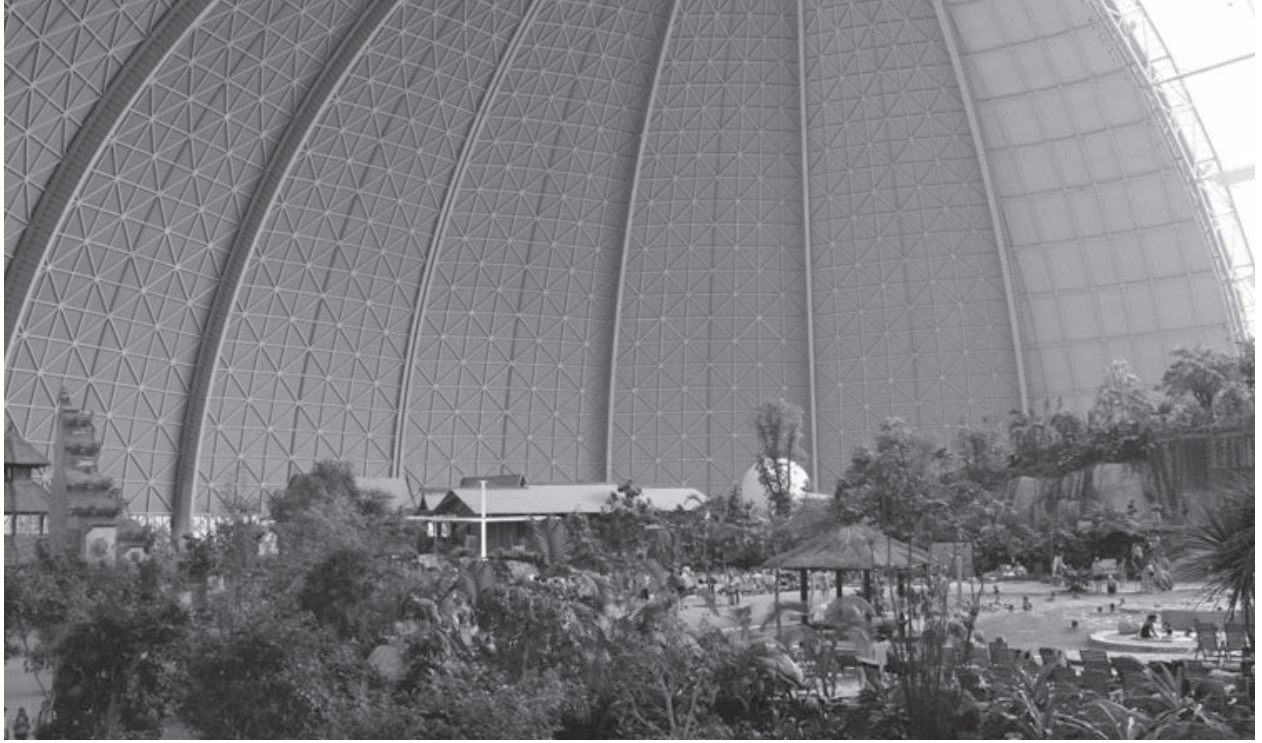

9. Some confusion prevails about what the "indigenous areas" are: a Sunday Times reporter believes the restaurants are of "Thai, Malaysian and Indonesian architectural style" or, simply, "oriental". These exotic spaces are further interiorised by filling them with homely elements, for instance with "plenty of German beer and wurst" (Eames, 2006). A global space for the public is created and filled with meaning in ways reminiscent of DiPaola's tropes.

10. Performers had to submit "reference letters from their pastors" (Leaupepe, 2005).
At Tropical Islands Resort, too, the world is brought into a vast interior. Signs such as, "Welcome to the One-World-Village" and "Peace Camp" make reference to global unity and peace. Exterior and interior morph in the resort's promotion as an "Island of eternal summer" (Allmaier, 2004). Village, islands, or world suggest topographies organized by different thresholds of inside and outside, but all contained by the resort's huge dome: Bali lagoon and South Sea; rainforest; waterfalls; rivers and spa pools; "several islands plus a sandy beach" (Eames, 2006). In a strangely familiar 'strange exterior space', visitors stroll along " $1.2 \mathrm{~km}$ of jungle pathways ... and enjoy cultural shows by 160 performers from the six indigenous areas" (dpa, 2004). ${ }^{9}$ However, which particular indigenous areas they are remains unclear, and a general multicultural con/fusion prevails at Tropical Islands Resort.

In the 2005 show "Call of the South Seas", more than eighty 'indigenous' performers further confused the strange cultural space: the all-Samoan troupe purported to represent all Pacific Islands. The scenario was staged by Samoan Tourism Authority's (STA) general manager Lesaisaea Reupena Matafeo, who convinced the organizers that it was unnecessary to involve several smaller groups from different Pacific Islands. Matafeo claimed that the Samoan troupe was able to perform all the dances: "We all know that our island dances differ slightly from each other and we don't look too different from each other" (in Leaupepe, 2005). It is not that the effects of visibility do not matter to the STA. Whilst rather generous on the multi-cultural side, the Samoan organizers ensured that only performers with a history of "good conduct" represented Samoa. ${ }^{10}$ However, their efforts to control regimes of visibility from a Samoan perspective - namely to have their culture portrayed in accordance with their own values while excluding other Pacific cultures - was frustrated by the Tropical Islands website designers' creation of a space of erotic power. The video, "Holiday and Night", exposes fragments of strange women from a mix of cultures, a topless glimpse included, all to the soundtrack of 'Pacific' music. Many Samoan contributors or observers would be dismayed to hear 'cultural' shows staged at Tropical Islands described as extravaganzas with "feathery headdresses, spangly bikinis and bottoms like J.Lo" (Eames, 2006).

A politics of aesthetics concerns the "partition of the sensible" (Rancière, 2000b: 8): historically and geographically specific modes of distributing time and space, and of visibility and intelligibility. Aesthetics provides in its image-spaces (interstices between immediacy and rational abstraction, appropriation and distance; see Brüggemann, 2002: 14, 51) a space of freedom from normal conditions and images of the possible. However, as long as objects and subjects are missing from the stages of globalized and virtualized environments (from nineteenth century world exhibitions to contemporary theme parks); as long as disagreement cannot take place, the question of whether or not enemies coexist in peace in these theatrical spaces is a mute question. 
Outside Tropical Islands Resort, the region is marked by conflicting histories that are still apparent, and which have introduced a great deal of 'third world' in the first. Successive and different imperialisms placed the hangar, like an alien spaceship, in the territory of what was formerly the largest military airbase outside the Soviet Union. Inside, with hardly anyone noticing, a former German colony makes an appearance: to Germans, if they can place it at all, Samoa today seems just like any other tropical island. Only an hour away from the re-established German metropolis Berlin, the resort is in many ways light years and worlds removed. Following German 're-unification', 1990s economic restructuring has left the region crippled and, as Europe is restructured within a global context, unemployment in Brandenburg has soared to around $21 \%$. Xenophobia is rampant. In the current order of consensus, while the resort's employees welcome visitors with smiles, in its surrounds, often at bus or railway stations, foreigners are regularly attacked by neo-Nazis.

Strangely, on a late mid-winter afternoon in 2006, the entrance area gives precisely the impression of an oversized railway station. As at airports, x-ray machines guard access to the theme park proper. Rancière's police needs technologies of counting and discounting. ${ }^{11}$

In this simulated miniature world, visitors' experiences are monitored and controlled in advance: at the entrance gates, they are equipped with electronic chips on wristbands. From the Balinese Gate, where the Tropical Village begins, to the Bali Pavilion, the Borneo Longhouse, the Thai House and the Samoan Fale they travel around the tropics within minutes.

Two stages provide near-constant entertainment and glimpses of exotic worlds. ${ }^{12}$ Only glimpses: what was invisible to the sun-searching Germans the performers entertained during the show "Call of the South Seas", was that the Samoans were freezing in a climate they were neither accustomed to, nor properly equipped for. Working exceedingly long hours, unable to leave the compound or their hotel, they eventually did not even earn enough to travel through Germany in summer. The resort's image space allowed visitors to see nothing but projections of their own desires. With the end of their contract, the Samoans' visibility faded away and was overlaid by a succession of new stimuli. In the website's video, the intelligibility of the fragments of their show has since diminished even further, and so has that of the Fale.

While the Fale's physical presence remains, the way in which it is staged obscures its historical and geopolitical context. On the website, it is described as a "typical Polynesian straw hut", "a sort of 'community house' for several villages". "It is particularly large and each of the 28 beautifully carved wooden posts represents one of the participating extended families" (Samoa Fale. Open Houses for living in the South Seas, 2005). The reference to harmonious community life is as unmistakable as the nostalgic flavour in the description of the Tropical Village's architecture: it was "built with authentic houses from 6 tropical regions of the world. They were constructed on site at Tropical Islands by craftsmen from their respective home countries" (The Tropical Village, 2005).

Claims to authenticity are often paired with realism in representation. ${ }^{13}$ Similarly, a bad translation is frequently characterized by excessive accuracy. However, Benjamin remarks, a translation must, rather then trying to resemble the
II. The "affirmation of 'objective givens' handled by the 'experts in power' is precisely the negation of the political; it defines what I have proposed to call 'the police"' (Rancière, 2000a: 124). Migrant workers, like the Samoan performers, are fragments of "the erstwhile worker" as much as the racists outside, "on whom sociologists significantly pin another color label, 'white trash"' (Rancière, 1999: 119). About the (police) desire to control conflict and shape a harmonious collective body, see also Buck-Morss (1992: 28).

12. Since its opening, Tropical Islands has featured Pacific, Brazilian, Cuban and Carribean shows.

13. Excessive realism in representation, and the will to control and contain, characterised the Egyptian exhibit at the 1869 Paris world exhibition (see Mitchell, 2002). A street made to resemble Cairo was painfully rendered in medieval decay and chaos, with even the façades made dirty. The streets were crowded, not only with make-believe Orientals, but fifty imported Egyptian donkeys. The mosque, like the whole street, was built as a façade. "As for the interior, it had been set up as a coffee house, where Egyptian girls performed dances with young males, and dervishes whirled" (Muhammad Amin Fikri in 1892, quoted in Mitchell, 2002: 497). Benjamin noted that during the 1867 Paris World Exhibition, "the 'oriental quarter' was the center of attraction" (2002: 18990). 


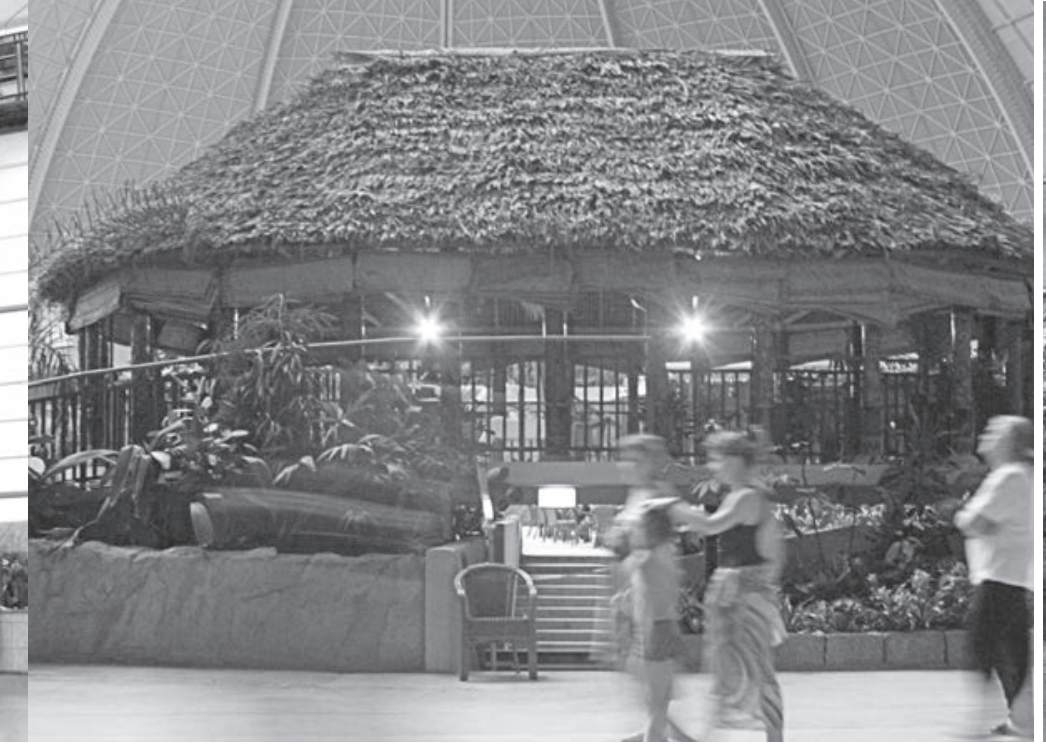

Samoan Fale. Photo:Sylvia Henrich, 2007.

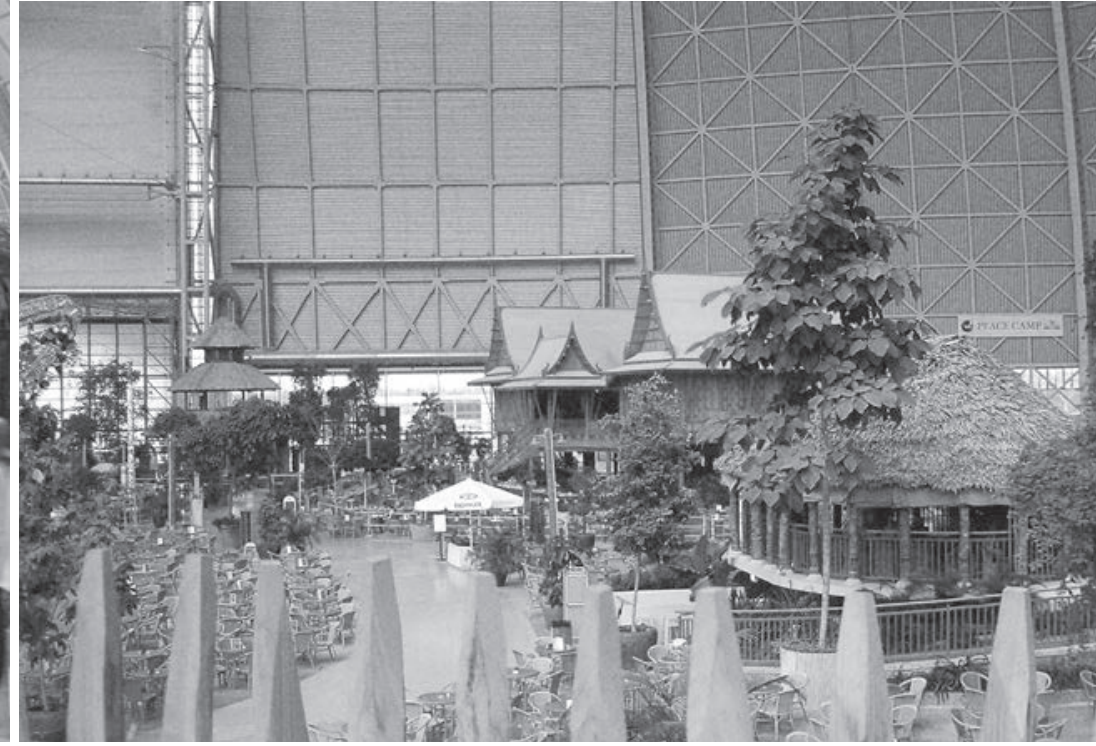

Samoan Fale in the Tropical Village. Photo: Author, 2007. episodes constantly demand to be taken as one's own personal fantasies and dreams. Productive distance is obliterated, and the conflict between what can and cannot be said is suppressed.

At Tropical Islands, some of the carefully selected Samoan performers had to be recalled home following "constant disorderly and drunken behaviour" (Sio, 2005, 25 May), perhaps induced by the "24/7 of fun" environment at the resort (Tropical Islands, 2005), or by their living and working conditions. ${ }^{16}$ Turned into objects of European fantasies, some Samoan performers may have preferred to disappear.

\section{Taking a Turn: When can disagreement take place?}

Tropes, turns, travels ... what they share are changing vistas and aspects, which will, however, be perceived in different ways. Travel in Tropical Islands is notliterally to travel around the world. Not all that have come here coexist in peace: neither are they enemies. There is no apparent consensus about a common world: neither is there obvious disagreement. If experiences are the "sensible configuration of [a] lived common wor[1]d", as Rancière holds (2003a: S4), then they seem out of step here. Disputes about what one sees and feels - "how it can be told and discussed, who is able to name it and argue about it" (S4) - which could lead to a common re-configuration of the sensible, do not take place. Insofar as the Tropical Village, the Samoan Fale and the show "Call of the South Seas" are translations of a foreign original into a local idiom, they could, potentially, express what remains repressed in a Samoan context. However, the configurations at the resort tend to obscure the common world rather than make it visible.

Interestingly, as Jean-Louis Déotte suggests, Rancière seems to overlook aspects of difference and dissonance (mésentente) that occur outside of situations in which speakers use the same terms in different ways. Within Western societies, voices that were previously unheard can indeed suddenly appear on the scene, forcing society to deal with their demands, ${ }^{17}$ so that those who had no share in politics "end by taking part" (2004: 81), since they belong to "a virtual community beyond social divisions ... made up of anyone and everyone" (86). Thus, the neo-Nazis with their violent dissensus, and the dissent expressed in the press regarding Tropical Island Resort's planning and implementation, are sometimes visible and audible.

However, Rancière's perspective is distinctively philosophical, and to an extent Eurocentric. It cannot account for "cases of intercultural différend, for which there
16. They may have suffered a similar degradation to that of the Egyptians in Paris, 1869, which "seemed as necessary to these spectacles as the scaffolded facades or the curious crowds of onlookers. The facades, the onlookers, and the degradation seemed all to belong to the organizing of an exhibit, to a particularly European concern with rendering the world up to be viewed" (Mitchell, 2002: 497).

17. See Deranty (2003). 
18. Symbolic apparatuses and industries (Déotte, 2004: 79) institute a political and cultural order that cannot be challenged from outside. They rely ultimately on a silently shared assumption that voice and visibility depend on articulate deliberation, argument, logos. Other forms of elaboration, narrative or revelation, find no place to be shared here (88). Emancipation à la Rancière, therefore, will defeat those other formswhich will survive as an ever growing remainder (88).

\section{See also note 4 above.}

20 For a distinction between dissent and dissensus, see Ostwald's contribution to this issue,page II, par 4.

21. The re-structuring appears to be based on a better understanding of the target market and has sadly led to an environment familiar to Germans from saunas on the outskirts of cities: factory halls filled with plaster and trompes d'oeuil of Mediterranean isles for the longing of the soul - all bound together by tons of tiles for the hygiene of the body.

22. I am using Hallward's adapted translation. would never be a common scene of interlocution" (86-7), and translation cannot even begin. In such situations, those outside (invisible and inaudible) not only have to accept the discursive norms of the 'virtual community' they are confronting, but also to explain themselves by them. They must also divide the sensible according to rules or laws that are alien to them (87). ${ }^{18}$ Rancière does not seem to consider the role of the différend as a cause of mésentente..$^{19}$ Besides, disagreement seems impossible, almost by definition, with an exotic that one loves to visit briefly and look at, but whom one does not want to become lastingly involved with (Beuchelt, 1987: 100).

Further, we tend to assume that everyone wants to be part of our virtual community of disagreement. What if they prefer not to? When discussing Tropical Islands in Samoa, sometimes I had a distinct sense of withdrawal: rather than disagreeing with Tropical Islands' handling of contracts or the use of the Fale, two interviewees (from quite different positions within a spectrum of opinion) placed responsibility with the resort's management, but preferred not to elaborate. ${ }^{20}$ On the other hand, Colin Au, who believed Tropical Islands would be successful because he knew "how the Germans tick", sought little involvement with locals in order to understand its context. Many Germans hunger for the tropical sun, but they may not care about cultural specifics and even be less interested in authenticity than $\mathrm{Au}$ believed. The visitors' interest in exotic cultures, beyond fleeting allusion, was not strong enough to sustain the resort as a viable business venture. At the end of 2006, Tropical Islands was restructured. While the notion of the world in a village is maintained, the village and the Fale, next to the children's fun park, are diminishing and the scene begins to look like an assembly of props. ${ }^{21}$ While to different degrees and in different roles, people have always participated at Tropical Islands, in the future it is likely that there will no longer be foreign 'villagers' with whom visitors could agree or disagree.

Given their interest in art and politics, perception and language, and the potential of ruptures and conflict to open up a space of visibility, it is not surprising that Rancière and Benjamin were also interested in the theatre and the stage. Rancière even defined politics as a theatrical performance of:

the gap between a place where the demos exists and a place where it does not ... Politics consists in playing or acting out this relationship, which means first setting it up as theatre, inventing the argument, in the double logical and dramatic sense of the term, connecting the unconnected (Rancière, 1999: 88). ${ }^{22}$

Benjamin recalls the final scenes in some plays, where actors enter the stage, fleeing. Brought to a standstill by their appearance on stage, they enter into "the visual field of nonparticipating and truly impartial persons [which] allows the harassed to draw breath, bathes them in new air". Correspondingly, there must be "a place, a light, a footlight glare, in which our flight through life may be likewise sheltered in the presence of onlooking strangers" (1934/1986: 91). The onlookers can actively and knowingly engage with the spectacle, precisely because they never wholly identify with it but, rather, draw on their own experiences, from a critical distance (Hallward, 2006: §13). These notions of the stage and its power are very different from what, currently, can be observed at Tropical Islands Resort. Closeness and distance, degrees of engagement and reflection, will play a role in creating the 
conditions under which disagreement becomes possible, and the partition of the sensible might change.

\section{References}

Allmaier, M. (2004). Palmen fürs Volk. Retrieved May 12, 2006, from http://zeus.zeit.de/ text/2004/52/Tropical_Island

Benjamin, W. (1934/1986). One-Way-Street (E. Jephcott, Trans.). In P. Demetz (Ed.), Walter Benjamin. Reflections: Essays, Aphorisms, Autobiographical Writings (pp. 61-96). New York: Schocken Books.

Benjamin, W. (1969a). On Language as Such and on the Language of Man. In H. Arendt (Ed.), Illuminations (pp. 314-332). New York: Schocken.

Benjamin, W. (1969b). The Task of the Translator. In H. Arendt (Ed.), Illuminations (pp. 69-82). New York: Schocken.

Benjamin, W. (1969c). Theses on the Philosophy of History. In H. Arendt (Ed.), Illuminations (pp. 253-264). New York: Schocken Books.

Benjamin, W. (1969d). The Work of Art in the Age of Mechanical Reproduction. In H. Arendt (Ed.), Illuminations (pp. 217-251). New York: Schocken.

Benjamin, W. (1996). Perception Is Reading. In M. Bullock \& M. W. Jennings (Eds.), Walter Benjamin. Selected Writings (Vol. 1, pp. 92). Cambridge (Mass): Harvard University Press.

Benjamin, W. (2002). The Arcades Project (H. Eiland \& K. McLaughlin, Trans.). Cambridge (Mass.): Harvard University Press.

Beuchelt, E. (1987). Zur Rezeption der Völkerausstellungen um 1900. In H. Pollig, S. Schlichtenmayer \& G. Baur-Burkarth (Eds.), Exotische Welten. Europäische Phantasien (pp. 98-105). Stuttgart: Institut für Auslandsbeziehungen \& Württembergischer Kunstverein.

Brüggemann, H. (2002). Architekturen des Augenblicks: Raum-Bilder und Bild-Räume einer urbanen Moderne in Literatur, Kunst und Architektur des 20. Jahrhunderts. Hannover: Offizin.

Buck-Morss, S. (1992). Aesthetics and Anaesthetics: Walter Benjamin's Artwork Essay Reconsidered. October, 62 (Autumn), 3-41.

Connolly, K. (2004, 21.12.). Germans get taste of tropics an hour's drive from Berlin. Retrieved May 1, 2006, from http://travelvideo.tv/news/more.php?id=A3758_0_1_0_M

Déotte, J.-L. (2004). The Differences Between Rancière's Mésentente (Political Disagreement) and Lyotard's Différend. SubStance: A Review of Theory and Literary Criticism, 33(1), 77-90.

Deranty, J.-P. (2003). Rancière and Contemporary Political Ontology. Theory E Event, 6(4), ss $1-37$.

DiPaola, K. (2004). Samoa - 'Perle' der deutschen Kolonien? 'Bilder' des exotischen Anderen in Geschichte(n) des 20. Jahrhunderts. Unpublished Doctor of Philosophy, University of Maryland, College Park.

dpa. (2004). World's largest indoor rainforest gets the nod. Retrieved March 3, 2006, from http://www.skyscrapercity.com/showthread.php?t=88305

Eames, A. (2006). Welcome to Germany's pleasure dome. Retrieved September 6, 2006, from http://travel.timesonline.co.uk/article/0,,10290-2187529,00.html

Goldmann, S. (1987). Zur Rezeption der Völkerausstellungen um 1900. In H. Pollig, S. Schlichtenmayer \& G. Baur-Burkarth (Eds.), Exotische Welten. Europäische Phantasien (pp. 88-93). Stuttgart: Institut für Auslandsbeziehungen \& Württembergischer Kunstverein.

Hallward, P. (2006). Staging Equality. On Rancière's Theatrocracy. New Left Review, 37(Jan/ Feb), 109-129.

Hendry, J. (2000). The Orient Strikes Back: A global view of cultural display. Oxford: Berg.

Holmes, B. (2001). Hieroglyphs of the Future: Jacques Rancière and the Aesthetics of Equality. Cabinet Magazine, 4(Fall). 
Kaiser, W. (n.d.). World exhibition 1851: the rat-race for progress. Retrieved May 1, 2006, from http://zis.uibk.ac.at/quellen/weltausstellungen/Kaiser_punch.html

Leaupepe, J. N. (2005). Dancing all the way to Germany. Retrieved May 3, 2006, from http:// www.samoaobserver.ws/news/local/ln0205/1905ln007.htm

The Mark of Kri on Playstation 2 - Long Read. (2003, August 2004). Retrieved September 5, 2004, from http://www.aocafe.com/forums/viewtopic.php?t=285\&postdays=0\&postorder $=$ asc\&start $=0 \&$ sid $=3$ be50c8fff5e574c7c3ac45bc22f0875\&5717af20b1e45d31238493a7a5adb7ff $=$ cba5bd666a943a65e238a5b582140ccf

Mersch, D. (n.d.). >Aisthesis<, >Ekstasis<, and >Askesis<. Movements of Avant-garde Art. Retrieved February 3, 2007, from http://www.momo-berlin.de/Mersch_Avantgarde.html

Mitchell, T. (2002). Orientalism and the Exhibitionary Order. In N. Mirzoeff (Ed.), The Visual Culture Reader (pp. 495-505). London: Routledge.

Rancière, J. (1999). Disagreement: Politics and Philosophy (J. Rose, Trans.). Minneapolis: University of Minnesota Press.

Rancière, J. (2000a). Dissenting Words. A Conversation With Jacques Rancière. diacritics, 30(2), 113-126.

Rancière, J. (2000b). Literature, Politics, Aesthetics: Approaches to Democratic Disagreement. Interview with Solange Guénoun and James H. Kavanagh. SubStance, 29(2), 3-24.

Rancière, J. (2002). The Aesthetic Revolution and its Outcomes. Emplotments of Autonomy and Heteronomy. New Left Review, 14(March-April).

Rancière, J. (2003a). Comment and Responses. Theory E Event, 6(4).

Rancière, J. (2003b). En allant à l'expo: l'ouvrier, sa femme, les machines. In Les Scènes du peuple: les révoltes logiques (pp. 63-84). Lyon: Horlieu.

Rancière, J. (2003c). The Politics of Aesthetics. Retrieved December 13, 2005, from http:// theater.kein.org/node/99

Rancière, J. (2004). Introducing Disagreement. Angelaki - Journal of the Theoretical Humanities, 9(3 December), 3-9.

Rancière, J. (2005, 16.01.2005). Statement on the occasion of the panel discussion: "Artists and Cultural Producers as Political Subjects. Opposition, Intervention, Participation, Emancipation in Times of Neo-liberal Globalisation". Paper presented at the symposium "Der Status des Politischen in aktueller Kunst und Kultur", 14-16 Januar 2005, Künstlerhaus Bethanien und Volksbühne am Rosa-Luxemburg-Platz, Berlin.

Rancière, J. (2006). Thinking between disciplines: an aesthetics of knowledge. PARRHESIA (1), 1-12.

Samoa Fale. Open Houses for living in the South Seas. (2005). Retrieved November 12, 2005, from http://www.my-tropical-islands.com/village/samoa-fale-e.htm

Schlehe, J. (2004). Themenparks: Globale Kulturrepräsentation, nation building oder Freizeitvergnügen? In K. Beck, T. Förster \& H. P. Hahn (Eds.), Blick nach vorn. Festgabe für Gerd Spittler (pp. 298-310). Köln: Rüdiger Koppe.

Sio, M. (2005, 25 May). 2 dancers being sent home from Germany. Retrieved May 13, 2006, from http://www.samoaobserver.ws/news/local/ln0505/2505ln004.htm

Steffen-Schrade, J. (1998). Exkurs: Samoaner im Frankfurter Zoo. In G. Kroeber-Wolf \& P. Mesenhöller (Eds.), Talofa! Samoa, Südsee - Ansichten und Einsichten (pp. 368-387). Frankfurt: Museum für Völkerkunde.

Taussig, M. (1992). Physiognomic Aspects of Visual Worlds. Visual Anthropology Review, $8(1), 15-28$

Toscano, A. (2006). Pedagogic Note on Jacques Rancière. Retrieved January 10, 2007, from http://roundtable.kein.org/node/402

Tropical Islands. (2005). Retrieved August 7, 2005, from http://www.my-tropical-islands. $\mathrm{com} /$

The Tropical Village. (2005). Retrieved November 12, 2005, from http://www.my-tropicalislands.com/village/index-e.htm 